Annals of Plant and Soil Research 23(2): 145-148 (2021)

https://doi.org/10.47815/apsr.2021.10047

\title{
Effect of combined use of fertilizer, bio-fertilizer and compost on yield and quality of chilli (Capsicum annum var. frutescence) cv. Pusa Jwala
}

\author{
VINIT KUMAR MEENA, SUTANU MAJI AND RAKESH KUMAR MEENA
}

Department of Horticulture, Babasaheb Bhimrao Ambedkar University, Vidya-Vihar, Rae Bareli Road, Lucknow, (U.P.) -226025

Received: October, 2020; Revised accepted, January, 2021

\begin{abstract}
An investigation was conducted to assess the effect of fertilizers, Azospirillum and compost (kitchen waste manure) on chilli (Capsicum annum var. frutescence) cv. Pusa Jwala at Babasaheb Bhimrao Ambedkar University, Lucknow (U.P.) during winter season of 2016-17. The twelve treatments were evaluated in a randomized block design with three replications. Results showed that the highest fresh weight of fruits per plant (575.73g), highest fruit yield (9212 $\mathrm{g} \mathrm{plot}^{-1}$ and $4.26 \mathrm{tha}^{-1}$ ) was recorded with 50\% RDF + kitchen waste manure (25 and 50 days after transplanting)] followed by RDF 50\% + Azospirillum (soil application at transplanting). However, the quality characters in terms of total soluble solids $(7.4 \%)$, ascorbic acid $(116.67 \mathrm{mg} / 100 \mathrm{~g}$ fruit), total sugars (2.5\%), reducing sugars (1.7\%) and non-reducing sugars $(0.8 \%)$ of fruits were observed better with Azospirillum treatment along with RDF i.e. RDF 50\% + Azospirillum (soil application at transplanting)]. It was also seen that combined effect of RDF and organic manures proved superior to RDF (100\%) sole application in respect of yield and quality of fruits. The lowest values of yield and quality parameters were recorded in control treatment.
\end{abstract}

Keywords: Manure, Azospirillum, quality, chilli, yield

\section{INTRODUCTION}

Chilli (Capsicum annum var. frutescence) is one of the most important vegetable crops grown throughout India. Chilli is an often-cross pollinated crop and the fruit is pendulous or erect, many seeded berry belonging to the Solanaceae family having chromosome number $\mathrm{n}=12$. Both ripe and green fruits are important condiment used for imparting pungency (due to Capsaicin) and have great potentiality both for domestic and international market. Since, Chilli is a heavy feeder crop so, it needs higher amount of nutrient (Meena et al., 2020). But, now a days, inorganic or chemical fertilizer reduce the soil fertility, plant growth, flowering and yield as well as it affects the quality of chilli. Chilli can be grown on wide range of soils but well drained, loamy soil rich in organic matter is the best suited for chilli cultivation with $\mathrm{pH} 5.5$ 6.5. Thus, bio-fertilizer like Azospirillum was used in chilli crop because it help to convert the atmospheric nitrogen in available nitrogen form and increases over all performance of crop including fruiting yield and biochemical properties in fruit. Kitchen waste manure is also a good source of nutrients because it is made from plant origin like leaves, flower, peel, seed etc. wastes from common house hold kitchen. Kitchen waste manure is not only provides good amount in nutrients (Tiwari et al., 2016), but also it helps to clean the area from garbage, reduce pollution and provide fresh air. It increase the microbial activity, soil porosity, water retention and reducing the $\mathrm{pH}$ level. Thus, the present study has a great significance on crop production as well as environmental issues of kitchen waste management. Hence, the present study was initiated using chilli as test crop.

\section{MATERIALS AND METHODS}

The experiment was carried out at the Horticulture Research Farm, Department of Horticulture, Babasaheb Bhimrao Ambedkar University, Lucknow during rabi season of 20162017. The experiment was laid out in randomized block design (RBD) with three replications and 12 treatments. The details of treatments were: $\mathrm{T}_{0^{-}}$Control, $\mathrm{T}_{1}-100 \% \mathrm{RDF}$ (NPK), $\mathrm{T}_{2}-$ RDF $50 \%+$ Azospirillum (soil application before transplanting), $\mathrm{T}_{4}$ - RDF $50 \%$ + Azospirillum (soil application at transplanting), $\mathrm{T}_{5}$ - RDF $50 \%+$ Azospirillum ( at 25 days after 
transplanting), $\mathrm{T}_{6}-\mathrm{RDF50} \%+$ Azospirillum (at 25 and 50 days after transplanting), $\mathrm{T}_{7}-\mathrm{RDF}$ $50 \%$ + kitchen waste manure (soil application before transplanting), $\mathrm{T}_{8}-\mathrm{RDF} 50 \%+$ kitchen waste manure (at the time of transplanting), $\mathrm{T}_{9}$ RDF $50 \%$ + kitchen waste manure (25 days after transplanting), $\mathrm{T}_{10}$ - RDF $50 \%$ + kitchen waste manure (25 and 50 days after transplanting), $T_{11}$ - $100 \%$ kitchen waste manure (at the time of transplanting). Before the seed sowing, the nursery field was ploughed, harrowed and the soil was brought to a fine tilt. Raised nursery beds were prepared at a height of $15 \mathrm{~cm}$ with $1 \mathrm{~m}$ width and $2 \mathrm{~m}$ length. Well-decomposed compost at $2 \mathrm{~kg}$ per meter cube and NPK fertilizers were applied 15 days before sowing. Seeds of chilli variety Pusa Jwala were sown after treating the seeds with 0.2 per cent Captan. Seeds were sown in rows and after sowing the lines were covered with fine FYM. Healthy seedling of 35 days old with 4-6 true leaves were transplanted in main field. Well-rotted Farmyard manure applied as per treatments one month prior to transplanting. The other inorganic sources of nitrogen, phosphorus and potassium were applied as per recommended dose i.e. 100: 50: $50 \mathrm{~kg} \mathrm{NPK} \mathrm{ha-1}$. Full dose of phosphorus and potassium and half dose of nitrogen was applied to the treatments having Azospirillum inoculation in a gap of 21 days. Remaining treatments without biofertilizers application received recommended dose of fertilizers in two splits. The roots of chilli seedlings were dipped in solution containing Azospirillum and left for 15 minutes before transplanting as per the treatment specifications. The solution was made by adding jaggary in sterile distilled water. After proper growth and development green chilli fruits were harvested and fruit yield were estimated multiplying average fruit weight and number of fruits harvested per plant and thereby yield per ha was calculated multiplying total number of plants in one hectare land with yield per plant. The quality parameters of fruits like TSS was analyzed using digital refractometer, ascorbic acid was measured using titration method using 2,6- dichlorophenol indophenols dye (Ranganna, 2001), Total, reducing and non reducing sugars were evaluated as per standard method of Thimmaiah (2006) using Fehling's solutions and methylene blue as indicator. The treatment observations were analysed as per standard statistical methods (Sahu and Das, 2014) and observations mean were compared at $5 \%$ level of significance.

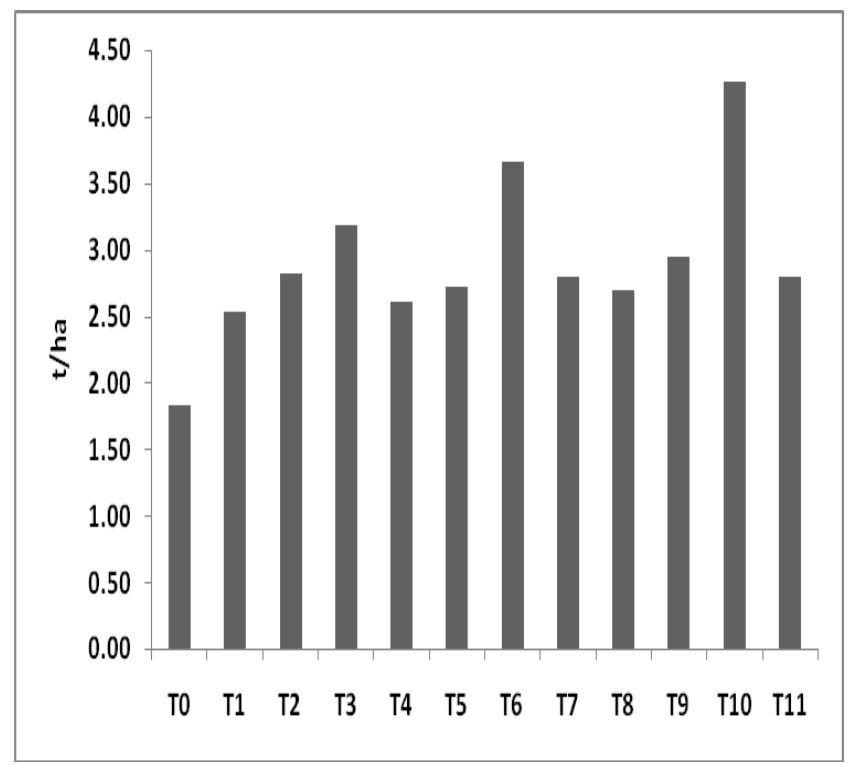

Fig. 1. Effect of integrated nutrient management on fruit yield of chilli cv. Pusa Jwala

\section{RESULTS AND DISCUSSION}

The data (Table 1) clearly showed that fruit weight of chilli was significantly highest (575.73 g per plant) with RDF $50 \%$ + kitchen waste manure $(25$ and 50 days after transplanting), followed by RDF $50 \%+$ Azospirillum (soil application at transplanting) $(495.58 \mathrm{~g})$. This increase in yield may be attributed to more availability of nutrients to plant and improvement in physico-chemical properties ofsoil due to addition of compost. Similarly, fruit yield per plot of chilli was highest $(9212 \mathrm{~g})$ under $50 \%$ RDF and kitchen waste manure applied at 25 and 50 days after transplanting), followed by RDF $50 \%+$ Azospirillum (soil application at transplanting) $(7929 \mathrm{~g})$ and $6876 \mathrm{~g}$ in RDF 50\% + Azospirillum (Seedling treatment). The minimum $(3973 \mathrm{~g})$ fruit yield per plot was recorded under control. The maximum green chilli yield $\left(4.26 \mathrm{t} \mathrm{ha}^{-1}\right)$ was also found with RDF $50 \%$ + kitchen waste manure (25 and 50 days after transplanting) as depicted in Fig.1. Similar results have been reported by Kumar et al. (2015) who reported that integrated use of fertilizers had higher vegetative growth resulting better photosynthates which might increased the fruit yield of chilli. 
Table 1: Effect of fertilizer, biofertilizer and kitchen waste manure on green fruit yield and quality of chilli cv. Pusa Jwala

\begin{tabular}{|c|c|c|c|c|c|c|c|c|}
\hline \multirow{3}{*}{ Treatment } & \multicolumn{3}{|c|}{ Yield parameters } & \multicolumn{6}{c|}{ Quality parameters } \\
\cline { 2 - 9 } & $\begin{array}{c}\text { Fruit weight } \\
\text { per plant }(\mathrm{g})\end{array}$ & $\begin{array}{c}\text { Fruit weight } \\
\text { per plot }(\mathrm{g})\end{array}$ & $\begin{array}{c}\text { Green } \\
\text { chilli yield } \\
\left.(\mathrm{t} \mathrm{ha})^{-1}\right)\end{array}$ & $\begin{array}{c}\text { Total } \\
\text { soluble } \\
\text { solids }(\%)\end{array}$ & $\begin{array}{c}\text { Ascorbic } \\
\text { acid }(\mathrm{mg} \\
\left.100 \mathrm{~g}^{-1}\right)\end{array}$ & $\begin{array}{c}\text { Total } \\
\text { sugars } \\
(\%)\end{array}$ & $\begin{array}{c}\text { Reducing } \\
\text { sugar } \\
(\%)\end{array}$ & $\begin{array}{c}\text { Non reducing } \\
\text { sugar } \\
(\%)\end{array}$ \\
\hline $\mathrm{T}_{0}$ & 248.3 & 3973 & 1.83 & 4.4 & 104.67 & 1.3 & 0.9 & 0.4 \\
$\mathrm{~T}_{1}$ & 341.4 & 5463 & 2.53 & 5.4 & 105.67 & 1.7 & 1.3 & 0.5 \\
$\mathrm{~T}_{2}$ & 380.5 & 6089 & 2.82 & 5.6 & 107.33 & 1.6 & 1.2 & 0.4 \\
$\mathrm{~T}_{3}$ & 429.7 & 6876 & 3.18 & 6.9 & 114.33 & 2.2 & 1.6 & 0.7 \\
$\mathrm{~T}_{4}$ & 353.4 & 5656 & 2.61 & 7.4 & 116.67 & 2.5 & 1.7 & 0.8 \\
$\mathrm{~T}_{5}$ & 368.5 & 5896 & 2.72 & 6.1 & 109.67 & 1.4 & 1.0 & 0.4 \\
$\mathrm{~T}_{6}$ & 495.5 & 7929 & 3.66 & 5.7 & 111.00 & 1.5 & 1.1 & 0.4 \\
$\mathrm{~T}_{7}$ & 376.8 & 6029 & 2.79 & 5.9 & 112.33 & 1.6 & 1.1 & 0.5 \\
$\mathrm{~T}_{8}$ & 384.6 & 6154 & 2.69 & 5.6 & 111.33 & 1.8 & 1.3 & 0.5 \\
$\mathrm{~T}_{9}$ & 399.3 & 6390 & 2.95 & 6.5 & 112.67 & 1.9 & 1.6 & 0.4 \\
$\mathrm{~T}_{10}$ & 575.3 & 9212 & 4.26 & 6.5 & 112.33 & 2.1 & 1.4 & 0.6 \\
$\mathrm{~T}_{11}$ & 376.1 & 6019 & 2.8 & 6.2 & 109.67 & 1.8 & 1.2 & 0.5 \\
$\mathrm{SEm}_{( \pm)}$ & 8.86 & 141.70 & 0.09 & 0.10 & 0.60 & 0.07 & 0.06 & 0.13 \\
$\mathrm{CD}(\mathrm{P}=0.05)$ & 26.14 & 418.26 & 0.28 & 0.30 & 1.78 & 0.21 & 0.19 & 0.04 \\
\hline
\end{tabular}

$T_{0}-$ Control, $T_{1}-100 \%$ RDF (NPK), $T_{2}-$ RDF 50\% + Azospirillum (soil application before transplanting), $T_{3}-R D F 50 \%+$ Azospirillum (Seedling treatment), $T_{4}-R D F 50 \%+$ Azospirillum (soil application at transplanting), $T_{5}-R D F 50 \%+$ Azospirillum ( at 25 days after transplanting), $T_{6}-$ RDF50 \% +Azospirillum (at 25 and 50 days after transplanting), $T_{7}-R D F$ $50 \%+$ kitchen waste manure (soil application before transplanting), $T_{8}-$ RDF 50\% + kitchen waste manure (at the time of transplanting ), $T_{9}-$ RDF 50\% + kitchen waste manure (25 days after transplanting), $T_{10}-R D F 50 \%$ + kitchen waste manure (25 and 50 days after transplanting ), $T_{11}-100 \%$ kitchen waste manure (at the time of transplanting)

Data (Table 1) also indicated that RDF $50 \%+$ Azospirillum (soil application at transplanting treatment)] showed maximum total soluble solids $(7.4 \%)$ of green mature fruit. Application of RDF $50 \%+$ Azospirillum (soil application at transplanting treatment) also showed maximum ascorbic acid (116.67 $\mathrm{mg} 100$ $\mathrm{g}^{-1}$ fruit) content in fruit, followed by $(114.33 \mathrm{mg}$ $100 \mathrm{~g}^{-1}$ fruit) [RDF 50\% + Azospirillum (seedling treatment)]. Panda et al. (2020) also reported similar resits in tomato. While, maximum total sugars $(2.5 \%)$ of fruit was observed in the treatment with RDF $50 \%+$ Azospirillum (soil application at transplanting treatment) followed by $2.2 \%$ total sugars in RDF $50 \%+$ Azospirillum (Seedling treatment) application. Similarly, Application of RDF $50 \%+$ Azospirillum (soil application) also showed maximum reducing sugars $(1.7 \%)$ of fruit which was very close to the effect of $50 \%$ RDF + Azospirillum (Seedling treatment), RDF $50 \%$ + kitchen waste manure (25 days after transplanting). The similar pattern was also recorded for non-reducing sugar where treatment RDF $50 \%+$ Azospirillum (soil application at transplanting treatment)] showed maximum non-reducing sugars $(0.8 \%)$ of fruit. Similar results have also been reported by Thamburaj and Singh (2015) and Kumar et al. (2016). Govind et al. (2015) and Nayak and Maji (2018) who also reported a significant effect on yield and quality of garlic and palak, respectively with the integrated use of kitchen waste manure which could be a good organic source of nutrients for plants as well as it also decreases the environmental pollution.

From the results, it may be concluded that the average fruit weight as well as fruit yield of green chilli was maximum with $50 \%$ RDF + kitchen waste manure (25 and 50 days after transplanting)], whereas, fruit quality in terms of total soluble solids, ascorbic acid, total sugars, reducing sugars and non-reducing sugars of fruit was better with the application of $50 \%$ RDF + Azospirillum (soil application). 


\section{REFERENCES}

Govind, Maji, S., Kumawat, R., Pal, A., Kumar, S. and Saha, S. (2015) Improvement of growth, yield and quality of garlic (Allium sativum L.) CV. G-282 through a novel approach. The Bioscan 10(1): 23-27.

Kumar, A.K., Sreehari, G. and Reddy, A. V. (2015) Integrated nutrient management in Chilli (Capsicum annum L.) under irrigated conditions in N.T. Zone of Andhra Pradesh. Research on Crops 7(2): 526-528.

Kumar, V., Sachan, C.P., Singh, S. and Sinha, A.K. (2016) Effect of INM practice on plant growth, fruit yield and yield attributes in chilli (Capsicum annuum I.). International Journal of Plant, Animal and Environmental Sciences 6(1):170-173.

Meena, V.K., Maji, Sutanu, Meena, R. K., and Meena, B. L. (2020) Effect of BioFertilizer and Kitchen Waste Manure on Growth of Chilli cv. Pusa Jwala. International Journal of Current Microbiology and Applied Sciences 9(6): 420-42.

Nayak, P.K. and Maji, S. (2018) Response of nutrient and cutting management for quality and green yield of Palak (Beta vulgaris var. bengalensis). Journal of Crop and Weed 14(1): 126-129.

Panda, D., Padhiary, A.K. and Mondal, S. (2020) Effect of panchagavya and jeevamrit on growth and yield of tomato (Solanum lycopersicum L). Annals of Plant and Soil Research 22(1): 80-85

Ranganna, S. (2001) Hand Book of Analysis and Quality Control for Fruits and Vegetable Products. $7^{\text {th }}$ Edition, Tata McGraw Hill Book Co., New Delhi, 594-625.

Sahu, P.K. and Das, A.K. (2014) Agriculture and Applied Statistics. Kalyani Pub.

Thamburaj, S. and Singh, Narendra. (2015) Text book of vegetables, tuber crops and spices. Indian Council of Agriculture Research New Delhi.

Thimmaiah, S.R. (2006) Standard methods of biochemical analysis. Kalyani Pub. Pp. 49-77

Tiwari, V., Maji, S., Kumar, S., Govind and Yadav, R. (2016) Use of kitchen waste based bio-organics for strawberry (Fragaria $\mathrm{x}$ ananassa Duch) production. African Journal of Agricultural Research 11(4): 259-265. 